\title{
Navigating the Turbulent Economic Waters of the 2007 Great Recession and the Crash of the Housing Market
}

By

\author{
Ali Hasbini, Sunrise Homes, Inc. and University of South Florida \\ Ronald K. Satterfield, University of South Florida
}

S ince the Great Depression, the U.S. housing market has significantly influenced economic production and employment levels. Direct and indirect investments in the housing industry, along with the induced economic activities such as real estate transactions and construction as well as other factors, accounted for an estimated $15-20 \%$ of GDP during boom years (CBPP, 2012).

The burst of the $\$ 8$ trillion housing bubble in 2007 and the
What triggered the crash of the U.S. housing market? This analysis looks at the economic and industry forces that led to an economic downturn that put as many as half of all U.S. residential builders out of business. cy filings (Quint, 2015). Concurrently, from 2006 through 2012, the Great Recession resulted in the loss of over $\$ 7$ trillion of home equity (Gould Ellen, 2012). Over 24 percent of home mortgages went "underwater" with balances exceeding home values (Carter \& Gottschalck, n.d.). For some homeowners, the unfortunate thought of losing their homes through foreclosure and incurring disruption to family life became a reality. The stress from threats of the loss of a home, unemployment, subsequent collapse of the financial markets in 2008 created massive disarray in homebuilding (Bivens, 2011). As many as 50\% of homebuilders closed their doors, either voluntarily or through bankrupt- and depletion of savings exacted a great toll on many. Not since the Great Depression has the U.S. economy faced forces so devastating to the housing market and personal wealth.

Keywords: Great Recession, Home Building, Housing Market, Economics, Financial Bubbles, Housing Bubbles, Business Failure, Financial Regulations, Sub-Prime Lending 
"We shape our dwellings, and afterward our dwellings shape us."

Winston Churchill

\section{The U.S. Housing Market}

Home ownership has long symbolized the American dream. For many, a home represents a large source of pride, savings, and wealth. It is not only a shelter for raising families, but also a place to make memories, live comfortably, and provide opportunities to improve one's life. Research has also indicated other benefits of home ownership, such as creating incentives for property enhancements, improvements in children's life outcomes, improving people's propensity to vote, and reducing crime rates (Zywicki \& Okolski, 2009). Home ownership in recent decades has been encouraged by U.S. government policies such as the interest mortgage deduction, progressive Housing and Urban Development (HUD) regulations, the Community Reinvestment Act (CRA), and homeownership targets set by the Clinton and Bush administrations (Zywicki \& Okolski, 2009). As shown in Figure 1, recent history has shown the homeownership rate in the U.S. averaged between $64-65 \%$, except for the period leading to the Great Recession, when it spiked to $69 \%$. Among 50 sampled nations the U.S. ranks 41st for homeownership which falls below Romania, Russia, and Cuba, among other others (Worldatlas.com).

Home ownership in America was once limited to farmers, who had the ability to establish a homestead on land they worked. With the industrial revolution and growth of urban dwellers home ownership became more common. Reforms of the National Bank Act in the late 1860's allowed banks to experiment with home mortgages. They became more popular in the 1890's with simple structures requiring a down payment of up to $50 \%$ followed by interest-only payments, and a balloon payment of principle made at the end of the loan. The typical term of those loans, however, did not exceed five years (Roth, 2016).

Following a decline in the great depression (19291940), home ownership rates increased dramatically, as shown in Figure 2. The post-war need for housing and the development of a better highway system created conditions for the development of the American suburb. Fast-growing cities like Levittown were based on a vision of communities of neat ranks of houses, each with its square of lawn, neighborhood public schools, picnic areas, and playgrounds. This became the idyllic manifestation of the middle class American dream (Blumgart, 2016).

Today the U.S. housing market represents the supply and demand of housing transactions between buyers, sellers, brokers, lenders, speculators, and others. At its core the housing market includes the resale market of existing homes as well as new residential construction. A broader definition incorporates the rental markets and the impacts of government housing policies and regulations. The economic impact of new housing construction is substantial due to materials procurement and construction processes of new homes and its labor intensity. On average new

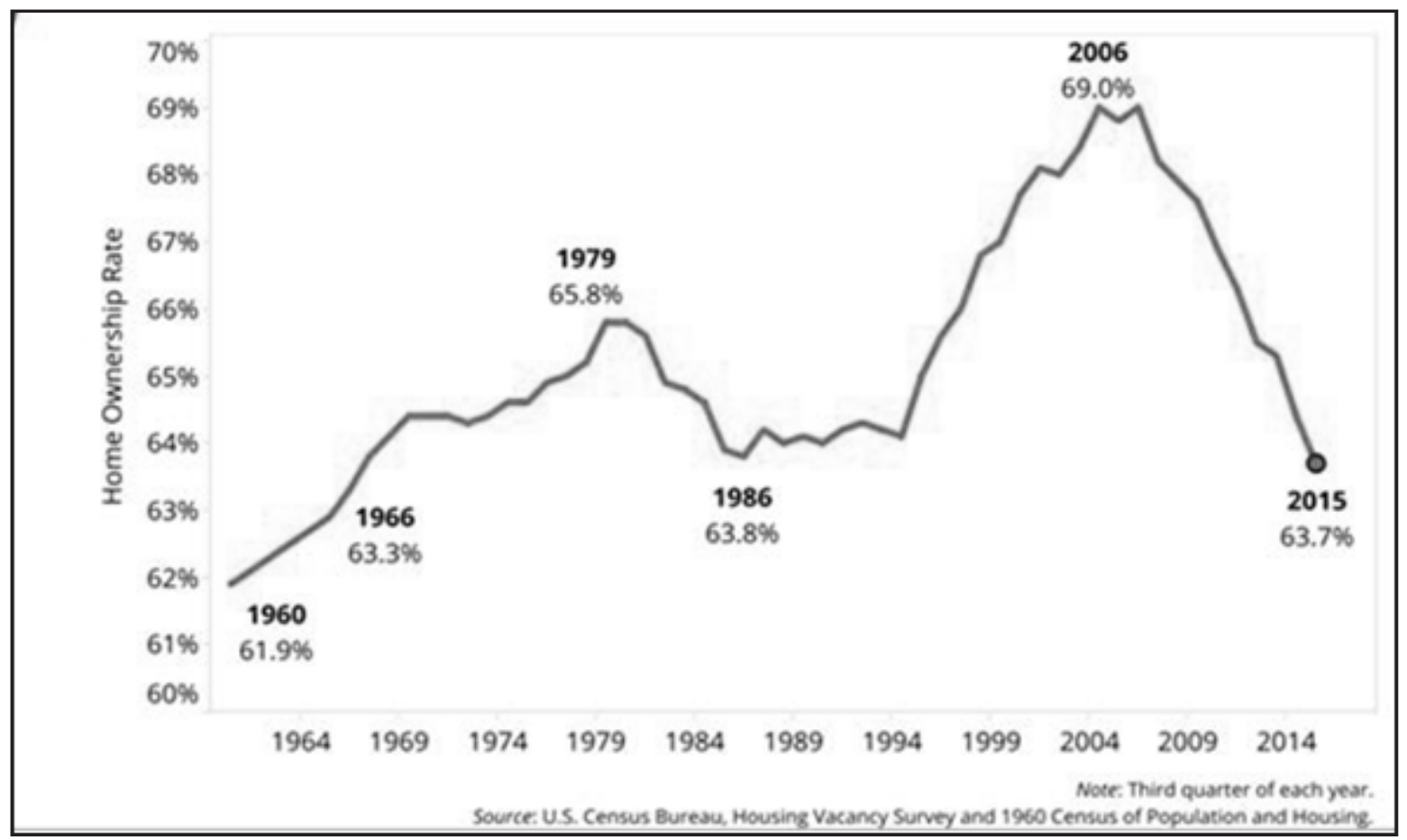

Figure 1: Home Ownership over Time 


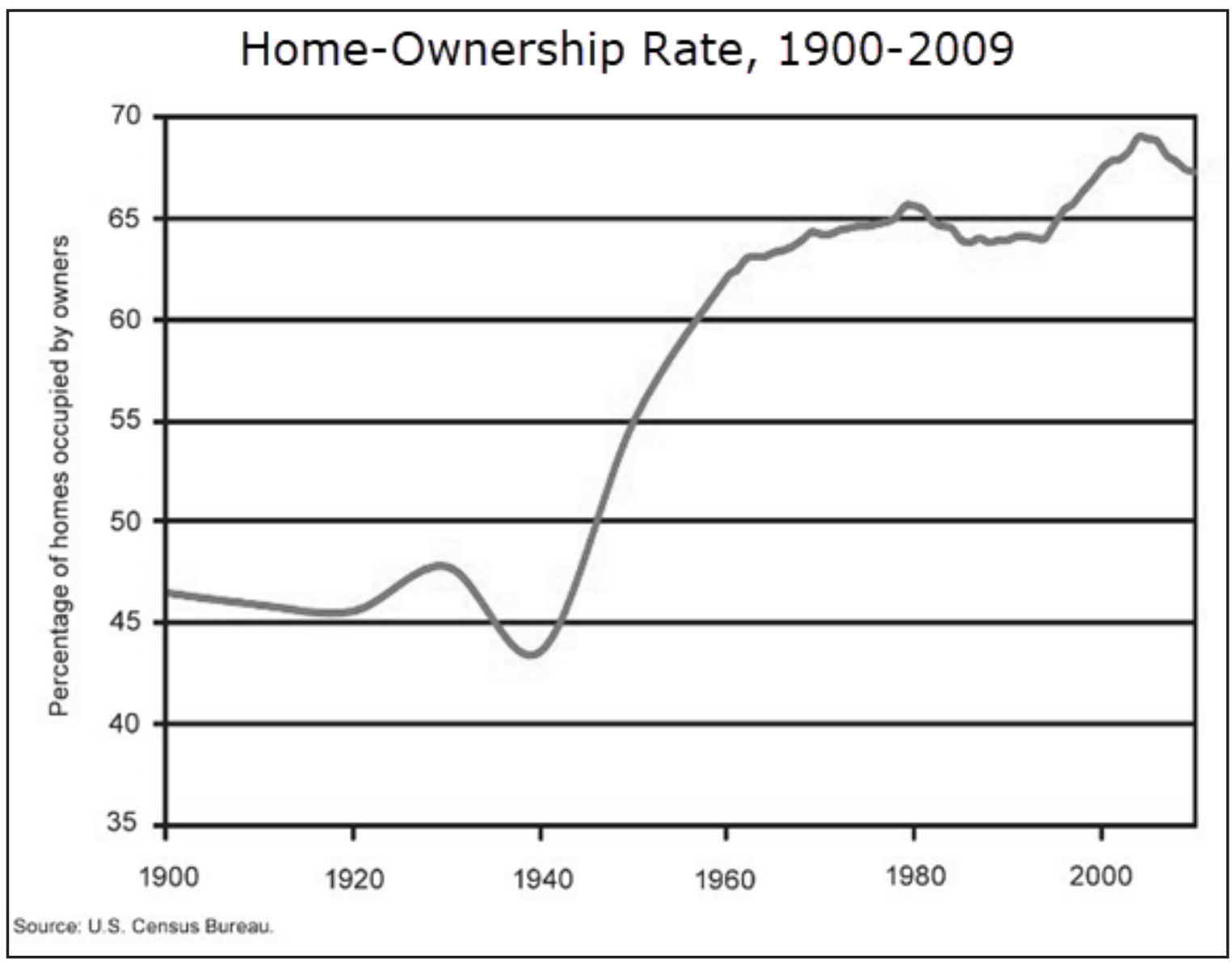

Figure 2: Home ownership rates in past century

housing contributes $5 \%$ to GDP, while consumer spending on housing-related activities and services contributes an additional 12-15\% (Independence Title, 2014).

Therefore, housing is a significant driver of economic activity with both direct and indirect impacts. Empirical research suggests that since World War II the new housing market has led society in and out of recessions (Woodward, 2015).

Resale housing, on the other hand, has little impact on GDP. Changes in home values correlate significantly with changes in consumption through either the wealth effect or the collateral effect. As the value of houses changes, households may feel more or less wealthy, which in turns affects their consumption and impacts economic growth and GDP. The same holds true for credit access when home values change, allowing households to borrow more or less against the value of their collateral, thus influencing consumer spending and consumption.

Within the housing market, the construction and purchase of newly built homes whether detached, attached, or multifamily has the greatest impact on GDP growth rates (Case et al., 2005). According to the National Association of Homebuilders (NAHB), homebuilding not only creates jobs directly, but its indirect ripple effect also contributes to the economy with goods, services, and taxes for local governments. The NAHB estimates that for every 100 single-family homes built in a typical local area, 394 jobs are created, $\$ 28.7$ million in local income is generated, and \$3.6 million in taxes are paid to local government. An additional recurring annual financial impact translates into 69 more local jobs, $\$ 4.1$ million in local income, and $\$ 1$ million in revenues for local government. Similarly, the construction of 100 apartment units creates 161 local jobs, $\$ 11.7$ million in income, and \$2.2 million in taxes for local governments. The recurring annual financial impact translates into an additional 44 jobs, $\$ 11.7$ million in income, and \$2.2 million in revenues for local governments (NAHB, 2015). Additionally, since homebuilding is labor intensive, any decline in the demand for housing will have a significant impact on the unemployment rate.

Many factors influence the demand for housing. Demographics, job creation, and employment top the list of factors affecting the ability of people to purchase a home, followed by affordability and financ- 


\section{Case Shiller Home Price Index}

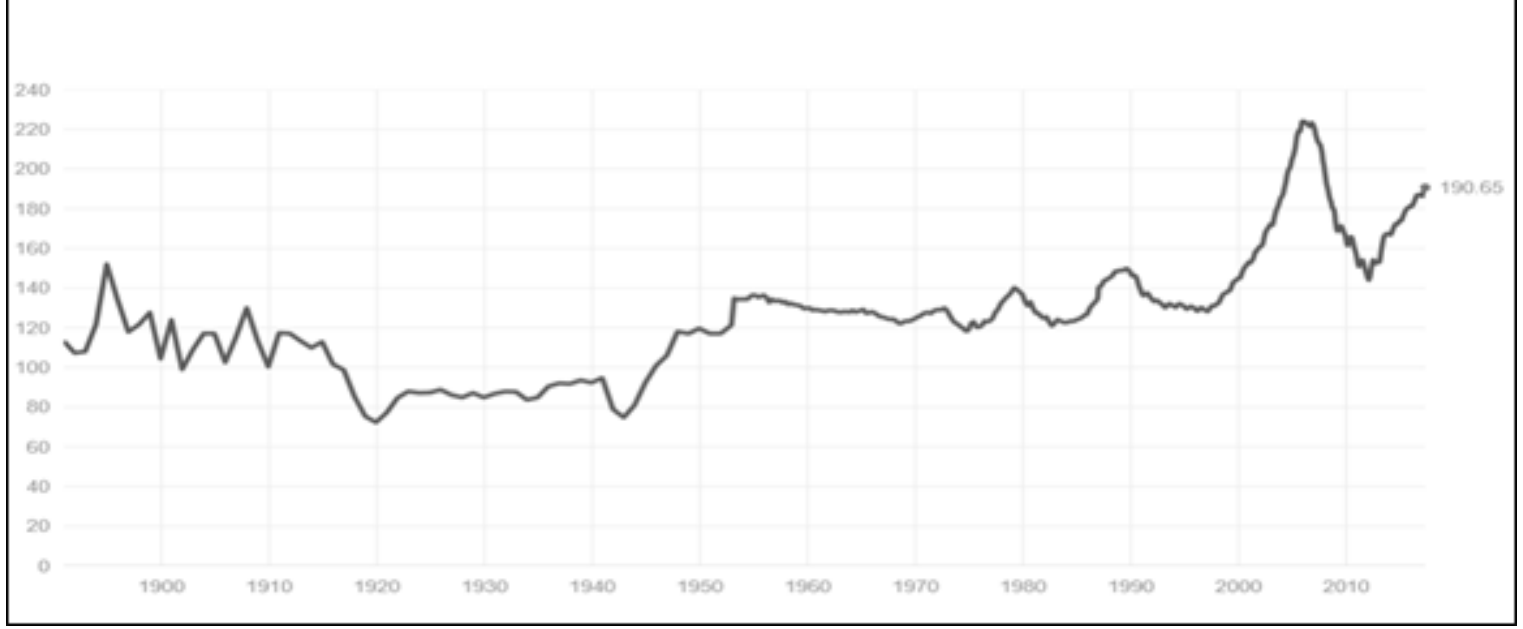

Figure 3: Case-Shiller Home Price Index (Retrieved from http://www.multpl.com/case-shiller-home-price-index-inflation-adjusted/)

ing availability. When the consumers' willingness to spend money increases, as represented by the consumer confidence index being in a normal range, the demand for housing improves (Greiner, 2015).

The housing market has faced serious challenges during the past century, but with the exception of the Great Depression of 1929 none led to the deterioration of home prices seen during the Great Recession of 2007 . Neither the $20 \%$ interest rates of the early 1980s, nor the decimation of the savings and loan industry in the early 1990s led to a similar crash of home values. It is also worth noting that not all economic downturns cool the housing market. In fact, during the 2001 recession, the housing market and housing demand remained strong despite the economic downturn, as shown in Figure 3. Home price appreciation stimulated consumer spending during that period, which kept the recession relatively short and shallow (Byun, 2010).

\section{Housing Bubbles}

Definition: "Temporary condition caused by unjustified speculation in the housing market that leads to a rapid increase in real estate prices. As with most economic bubbles, it eventually bursts, resulting in a quick decline in prices. The end of a housing bubble is hard to predict given the fact that economic conditions can change without warning. If a housing bubble swells to an extremely high level, the aftermath of a burst may set the housing market back years" (businessdictionary. com/definition/housing-bubble).

The world has witnessed numerous asset bubbles over the years. Examples include the Dutch Tulip bubble of the 1500s, the South Seas bubble in the 1700s, the Gold Rush of 1849, the forgotten U.S. real estate bubble of the 1920s, and the Japanese real estate and stock market bubble in the 1980s (HBS, 2017; Smith, 1935). Recently we have seen the effect of the dot-com bubble in 2000s and the housing bubble of 2006. Although these examples all have common denominators, they differed in severity and their occurrence was difficult to predict. Typically a bubble forms when the price or value of the underlying financial asset increases to levels far exceeding its historical norm or intrinsic value. Participants ignore cautionary signs, holding to an inflated and unrealistic belief about, or even indifference as to what that intrinsic value may be (Picardo, 2015).

The 19th century recorded the first real estate bubbles in the U.S. with the sale of public lands by the Federal Government. The cycle of peak and valley in land speculation and sales has typically lasted 18 years (Hanke, 2010). Housing bubbles are usually defined as a periodic form of economic bubble which usually occur following a marked increase in housing prices. Although housing bubbles have been less frequent than other bubbles, they are more damaging due to their longevity and output losses (Helbing \& Terrones, 2003). Compared with other assets, particularly equities, housing prices take much longer to recover after the bubble bursts (Reinhart \& Rogoff, 2009, p. 161).

Housing bubbles typically form organically with population growth when a new generation reaches home buying age. This growth creates new households, thus increasing housing demand. With other factors such as the entry of immigrants into the housing market, impacts of speculators, good economic conditions, low-interest rates, and abundant financing options, prices are bound to rise. With the 
time lag in construction, increased demand causes prices to rise. When home prices deviate substantially from underlying, demographically derived organic demand, then a burst is likely to occur--sending the general economy into a crisis. In some instances a bubble burst can be easily brought about by some catalyst that shocks the economic system. Examples include natural disasters, government actions, war, fear of political or economic instability at home or abroad, and threats to energy supplies. One such catalyst was the 1926 hurricane in Florida that pricked the real estate bubble of the 1920's. This led to an increase in the foreclosure rate which continued into the Great Depression (White, 2009).

Economists argue over the starting date of the 2006 housing bubble. Thomas Lawler, former senior vice president at Fannie Mae, claims that 2002 represents the kick-off date for the bubble. He argued that after the dot-com bubble and the 2000 recession, investors were seeking more stable investments and real estate presented the perfect opportunity. Given the low interest rates set by the Federal Reserve to support the economy, the availability of financing, and relaxed mortgage standards, homebuyers had strong incentives to purchase a home.

However, economist Robert Shiller points to a much earlier date. Examining the 10-city composite home-price-index shows that the index rose between 1995 and 2006. This would place the housing bubble's start in the mid 90's.

There were plenty of advance warning signs of the 2006 housing bubble burst which pointed to a financial crash and a severe housing market correction. Some economists and political analysts predicted the bubble and its burst in the early 2000s. Professor Robert Shiller wrote about the pending bubble burst in his "Irrational Exuberance" publication. Dean Baker also identified the bubble and repeatedly warned about its implications (Baker, 2002). Sir Andrew Large, the Deputy Governor of the Bank of England, cautioned in 2004 about the dangers of excessive borrowing and an imminent crash. In 2005 the chief economist of the International Monetary Fund (IMF), Raghuram Rajan warned of catastrophic consequences to the financial system due to deregulation, institutional moves, and risk taking resulting from the housing bubble. Fed Chairman Alan Greenspan and former Treasury Secretary Larry Summers, who were present at the conference, discounted the warning as "largely misguided." (Denning, 2011).

Late in 2005 and throughout 2006, the business press and media were inundated with reports of an immi- nent threat to the economy from the housing bubble. Among the many who also sounded the alarm, NYU Economist Nouriel Roubini warned the housing market was following a "free fall" trajectory which might derail the entire U.S. economy, bringing on a recession. During the same period, Mark Zandi, Chief Economist for Moody's research firm, warned of a double-digit decline in home values leading to a crash during the 2007-2009 period. By mid-summer 2007 Yale economist Robert Shiller indicated real home prices would sharply decline in the notso-distant future, predicting a 50\% drop in value in certain regions of the country (Bianco, 2008).

\section{The Great Recession of 2007}

By most accounts, the Great Recession of 2007 caused the United States its worst and longest economic downturn since the Great Depression. Beginning with the burst of the housing bubble, U.S. GDP started its fall into negative territory with a significant decline in economic activity across the country. The National Bureau of Economic Research (NBER), a private non-profit research organization, officially declared the start of the recession in December, 2007 and recorded its end in June, 2009. As shown in Figure 4 (next page), the NBER considers a list of economic indicators when dating recessions, which include real personal income, industrial production, retail sales, nonfarm employment, and

GDP growth.

Economists dubbed it the "Great Recession" due to its severity and extended duration, with global ramifications affecting most of the advanced economies of the world (Dao \& Loungani, 2010). The effects on U.S. households of this severe economic downturn were devastating. Unemployment rose to $10 \%$ in many parts of the country and remained high long after the recession ended. In many regions home values dropped between 15\% and $45 \%$ from their highs while stock market indices lost $50 \%$ of their values. The Dow Jones Industrial Average dropped 55\% from a high of 14279 in October, 2007 to 6440 in March, 2008. When combined, these effects led to a reduction of $38.8 \%$ in the net worth of the average American family (Bricker et al., 2012). The collateral damages resulting from the mortgage meltdown were numerous. As home prices fell, property tax revenues collected by local governments dropped.

Homeless rates rose with more families losing their homes to foreclosures. Rental tenants were affected when landlords lost their investment rental properties. Researchers attributed other indirect and disturbing effects to this economic instability: an 


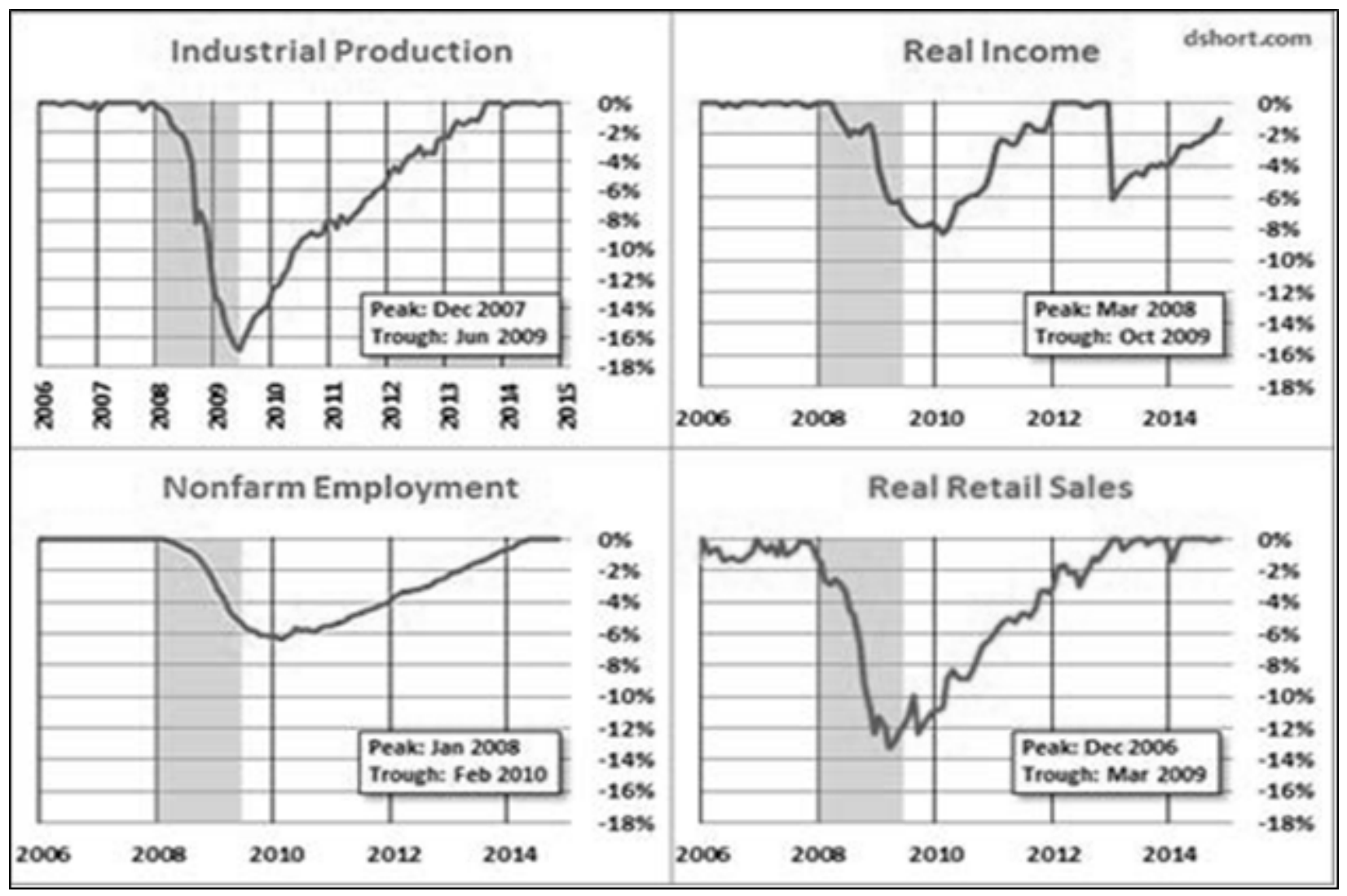

Figure 4: Indicators of the beginning of the recession from the National Bureau of Economic Research

increase in health- and stress-related ailments such as heart attacks (Burgard et al., 2007), a reduction in societal cohesion (Giuliano \& Spilimbergo, 2009), and even a reduction in the academic performance of many students of laid-off parents (Stevens \& Schaller, 2009).

This financial turbulence also devastated large financial organizations, which led to the financial crisis. Many firms were in such financial distress that only government intervention was able to save them. Bear Stearns, the prestigious investment banking firm founded in 1923 and recognized as the "Most Admired" securities firm in Fortune's "America's Most Admired Companies" survey three years earlier, was in such dire financial need that the Federal Reserve had to intervene to facilitate its acquisition by JP Morgan (Business Wire, 2005). Others claimed that without a government bailout of the multinational insurance corporation American International Group, Inc., also known as AIG, the U.S. financial system would have been in jeopardy and its demise would have affected the entire global economy (Amadeo, 2017). Accordingly, Bank of America, Citigroup, and other financial institutions received billions of dollars in loans and guarantees needed to shore up their balance sheets and preserve confidence in the banking system. Lehman Brothers, on the other hand, filed for bankruptcy when the
Treasury Department refused to bail them out after negotiations for the sale of the company fell apart. Others ended up with the same fate causing panic among global bankers, thereby adding more fuel to the fire of the Great Recession.

The Federal Government, through its executive and legislative branches, had to react quickly. In late 2008 and early 2009 the Troubled Asset Relief Program (TARP), a financial stabilization measure, and the fiscal stimulus of the American Recovery and Reinvestment Act (ARRA) were enacted. The objective was to calm the financial markets swiftly, boost the demand for goods and services, and help preserve and create jobs during the recovery period. The Congressional Budget Office found that improvements to GDP and the unemployment rate were a direct result of ARRA, and the recovery would have been much slower without its implementation (CBPP, 2017).

The Federal Reserve also responded decisively to the crisis by using creative tools from its toolbox. The initial Fed response was the "traditional" reduction of the Federal Funds rate from 5.25\% in September of 2007 to $0-.25 \%$ during 2008 . Non-traditional policy measures then focused on easing the credit situation and improving the economy's cash flow. The Large-Scale Asset Purchase program (LSAP) was implemented to lower long-term borrowing rates 
for the private and public sectors by the purchase of mortgage-backed securities and debts of government sponsored entities such as GSE's, Fannie Mae, Freddie Mac, and the Federal Home Loan Bank (Gagnon et al., 2010).

Major changes in financial regulations and banking also resulted from the financial crisis. With the turmoil in the financial markets subsiding in 2010, Congress enacted the Dodd-Frank Act, which was intended to reform and safeguard the financial sector and reduce the risks of financial distress, especially for large financial organizations. New regulations, for example, allowed the Federal Reserve to oversee nontraditional credit intermediaries designated as "Systematically Important Financial Institutions." The Act also authorized the Federal Deposit Insurance Corporation to liquidate financial institutions if they deemed their failure would negatively affect the financial system. Other measures required large financial institutions to create detailed exit strategies, should they face liquidation in bankruptcy courts, without having to ask for government intervention. Traditional banks were also required to increase their capital balances, reduce dividend payments to build capi-

tal, and conduct regular stress testing to deal with unforeseen hidden risks

The formation of the housing bubble followed a unique pattern. Initially, public policies depressed short-term rates and encouraged homeownership. Homebuyers saw great opportunities to improve their lives with home purchases. Financial institutions devised customized lending programs, and mortgages packaged as investment commodities were sold on the open market, bringing in millions in fees. Demand for housing skyrocketed and pushed prices higher, attracting speculators wanting to cash in on the abundant opportunities. Collectively, those activities formed upward pricing pressure and opened the floodgates for additional residential lending, creating a hyperactive and unsustainable demand for housing. The result was an unprecedented rise in home prices that was destined to collapse. Apparent from the evidence, this housing bubble was driven and sustained by the main ingredients of a classical bubble: a substantial liquidity source causing it to inflate, homebuyers and investors believing that they had opportunities to achieve higher returns without additional risks, and market inefficiencies and regulatory failures allowing the bubble to inflate without resistance (Krugman, 2009b).

The subsequent chain of events triggered a rapid decline in home values, leading to massive foreclosures and the ensuing collapse of the housing market. It be- gan with the increase of rates in adjustable rate mortgages during the latter part of 2005 and throughout 2006. Some subprime and prime borrowers were able to refinance or sell their properties, but many were unable to make higher mortgage payments and defaulted. By mid-summer of 2006 delinquencies in the mortgage pools of securities started to rise, causing investors to stop buying securitized mortgages. Funding for new mortgages and refinances ceased, with real estate speculators exiting the market in droves while dumping even more homes, and pushing values down further. Throughout 2007 and 2008, a number of hedge funds and investment bankers failed while banks stopped lending money to each other fearing defaults. Making matters worse, the sources of business funding dried up and companies unrelated to housing struggled, resulting in more job losses. With a faltering economy, layoffs in many industries were rampant, forcing more homeowners to default. Foreclosures became inevitable, and the numbers were mounting.

A key consideration by homeowners on whether to default on a mortgage is the amount of equity accrued in a home. Adverse life events such as natural disasters, illness, divorce, and job loss can trigger delinquencies and result in foreclosures (Zywicki \& Okolski, 2009). During the bubble, exotic and high loan-to-value mortgages with low initial interest rates were offered to prime and subprime borrowers.

These required little or no down payment and thus gave rise to a payment shock when they reset to higher rates. Additionally, home-equity loans put in place by homeowners to finance a multitude of lifestyle expenditures such as vehicles and vacations, added another layer of debt and consumed accumulated equity. The rapid fall in home values resulted in negative equity, giving homeowners strong incentives to default. Since foreclosure rates and drop in home values are strongly correlated, by the middle of the recession one in four home mortgages were "underwater" (Zywicki \& Okolski, 2009).

\section{Literature Review}

A comprehensive literature review formed the basis of this study. In this review we examined previous bubbles and recessions, the activities of the financial markets, the regulatory environment for the period preceding the housing market collapse, and the impact of the housing market crash.

\section{Literature Summary}

A broad summary of this review is given in Table 1 
Table 1: Primary causes of the housing bubble that led to the financial crisis

\begin{tabular}{|c|c|c|}
\hline Construct & Findings & Source \\
\hline \multirow[t]{6}{*}{$\begin{array}{l}\text { Government Monetary } \\
\text { and Housing Policies }\end{array}$} & $\begin{array}{l}\text { The government allowed weak lending standards which } \\
\text { stimulated speculation and later defaults when rates } \\
\text { increased. }\end{array}$ & $\begin{array}{l}\text { Liebowitz } \\
(2008) \text {. }\end{array}$ \\
\hline & $\begin{array}{l}\text { Flawed housing and monetary policies by the government } \\
\text { were the main causes of the crisis. These included down } \\
\text { payment requirements by HUD, CRA rules, subsidizing } \\
\text { GSE's, and pushing for the granting of sub-prime loans. }\end{array}$ & White (2009). \\
\hline & $\begin{array}{l}\text { Land restrictions imposed by local governments limited } \\
\text { the supply of land for housing, which led to substantial } \\
\text { appreciation in home prices. }\end{array}$ & Sowell (2009). \\
\hline & $\begin{array}{l}\text { Foreign savings flowing into the U.S. economy provided } \\
\text { cheap and easy credit to both households and businesses, } \\
\text { resulting in a housing boom. }\end{array}$ & Bernanke (2009). \\
\hline & $\begin{array}{l}\text { Low short-term rates by the Fed pushed yields for munic- } \\
\text { ipal and government bonds lower, forcing asset managers } \\
\text { toward higher yield, but riskier mortgage-backed securi- } \\
\text { ties. Also, the } 1998 \text { repeal of the Glass-Steagall Act, which } \\
\text { was intended to protect the banking system. }\end{array}$ & Ritholtz (2011). \\
\hline & $\begin{array}{l}\text { The huge push for homeownership by HUD increased } \\
\text { pressure on the GSEs to provide mortgages for people of } \\
\text { low and modest income. }\end{array}$ & $\begin{array}{l}\text { Engel \& McCoy } \\
(2016) .\end{array}$ \\
\hline \multirow[t]{7}{*}{$\begin{array}{l}\text { Shadow Banking } \\
\text { System and Financial } \\
\text { Engineering: the Securi- } \\
\text { tization of Mortgages }\end{array}$} & $\begin{array}{l}\text { The panic of the "shadow banking system" resulted in } \\
\text { insolvency when financial firms refused to increase the } \\
\text { margins on repo agreements or renew the sale and repur- } \\
\text { chase of those agreements. }\end{array}$ & Gorton (2010). \\
\hline & $\begin{array}{l}\text { The unregulated "shadow banking system" hedge funds } \\
\text { and investment bankers fed the housing bubble while } \\
\text { becoming highly leveraged and later failing. }\end{array}$ & $\begin{array}{l}\text { Krugman } \\
(2009 b)\end{array}$ \\
\hline & $\begin{array}{l}\text { Mortgage credit expansions into subprime zip codes pro- } \\
\text { vided a greater number of riskier securitized mortgages, } \\
\text { thus leading to the bubble and crisis. }\end{array}$ & $\begin{array}{l}\text { Mian \&. Sufi } \\
\text { (2009). }\end{array}$ \\
\hline & $\begin{array}{l}\text { Loans that were securitized and sold had a higher foreclo- } \\
\text { sure rate than loans held in banks' portfolios. }\end{array}$ & $\begin{array}{l}\text { Vig, Seru, \& Pis- } \\
\text { korski (2009). }\end{array}$ \\
\hline & $\begin{array}{l}\text { Increased securitization of mortgages into mort- } \\
\text { gage-backed securities led to the lowering of lending } \\
\text { standards. }\end{array}$ & Zandi (2008). \\
\hline & $\begin{array}{l}\text { The "global savings glut" from emerging economies, seek- } \\
\text { ing safe returns, ultimately found its way into the U.S. real } \\
\text { estate market. This cheap capital funded mortgage-backed } \\
\text { securities thereby fueling the housing bubble. }\end{array}$ & $\begin{array}{l}\text { Jagannathan } \\
\text { (2013). }\end{array}$ \\
\hline & $\begin{array}{l}\text { Securitization allowed lenders to transfer the default risk } \\
\text { of mortgage-backed-securities to investors, thereby creat- } \\
\text { ing a moral hazard. }\end{array}$ & $\begin{array}{l}\text { Engel \& McCoy } \\
(2011) .\end{array}$ \\
\hline
\end{tabular}




\begin{tabular}{|c|c|c|}
\hline \multirow[t]{5}{*}{ Subprime Market } & $\begin{array}{l}\text { Sub-prime borrowers did not cause the housing crash } \\
\text { as early data suggested. The prime market was at least as } \\
\text { responsible. }\end{array}$ & $\begin{array}{l}\text { Ferreira \& } \\
\text { Gyourko (2015). }\end{array}$ \\
\hline & $\begin{array}{l}\text { The expansion of mortgage credit into subprime zip codes } \\
\text { and the increase of securitization of those mortgages sig- } \\
\text { nificantly contributed to the default crisis. }\end{array}$ & $\begin{array}{l}\text { Mian \& Sufi } \\
(2009) \text {. }\end{array}$ \\
\hline & $\begin{array}{l}\text { The quality of subprime mortgages deteriorated long } \\
\text { before the onset of the Great Recession. It could have } \\
\text { been detected earlier, except that escalating home prices } \\
\text { concealed the problem. }\end{array}$ & $\begin{array}{l}\text { Demyanyk \& } \\
\text { Van Hemert } \\
\text { (2011). }\end{array}$ \\
\hline & $\begin{array}{l}\text { The subprime lending market experienced a dramatic } \\
\text { increase in the number of high loan-to-value (LTV) ratio } \\
\text { loans toward the latter part of the housing boom. With } \\
\text { prices rising, these loans performed well. When prices } \\
\text { dropped, those loans caused borrowers to default. }\end{array}$ & Gerardi (2008). \\
\hline & $\begin{array}{l}\text { Home loans issued in subprime zip codes were not aimed } \\
\text { at the poor. Later mortgage losses were due to high- and } \\
\text { middle-income borrowers. Also, mortgage debt burdens } \\
\text { as measured by debt-to-income ratio did not change from } \\
\text { pre-bubble period. }\end{array}$ & $\begin{array}{l}\text { Adelino, Scho- } \\
\text { ar, \& Severino } \\
(2016) \text {. }\end{array}$ \\
\hline \multirow[t]{3}{*}{$\begin{array}{l}\text { Lending products and } \\
\text { Underwriting Standards }\end{array}$} & $\begin{array}{l}\text { Increased debt to income ratios, low short-term rates by } \\
\text { the Federal Reserve, relaxed mortgage lending standards, } \\
\text { and increased leveraging by the investment bankers pro- } \\
\text { duced the crash. }\end{array}$ & $\begin{array}{l}\text { Gwartney, } \\
\text { Macpherson, } \\
\text { Sobel, \& Stroup } \\
\text { (2008). }\end{array}$ \\
\hline & $\begin{array}{l}\text { Lenders reduced their mortgage underwriting standards } \\
\text { to meet the requirements of the Community Reinvest- } \\
\text { ment Act. GSEs responded to HUD requests by reducing } \\
\text { income and down payment requirements. }\end{array}$ & Holt (2009). \\
\hline & $\begin{array}{l}\text { The "moral hazard" effect led to lax mortgage standards as } \\
\text { the risk of the transactions shifted to the next player. }\end{array}$ & Bianco (2008). \\
\hline \multirow[t]{4}{*}{$\begin{array}{l}\text { Other Contributing } \\
\text { Factors }\end{array}$} & $\begin{array}{l}\text { Shiller emphasized the irrational exuberance of all players } \\
\text { as the lead cause of the bubble. }\end{array}$ & Shiller (2012). \\
\hline & $\begin{array}{l}\text { Authors identified factors that contributed to the bubble, } \\
\text { including the excess supply of housing units during the } \\
\text { boom, changes in demographics, quality of housing, and } \\
\text { restructuring of the housing industry. }\end{array}$ & $\begin{array}{l}\text { Haughwout, } \\
\text { Peach, Sporn, \& } \\
\text { Tracy (2012). }\end{array}$ \\
\hline & $\begin{array}{l}\text { The irrational demand for housing resulted in higher pric- } \\
\text { es and extended the duration of the bubble. }\end{array}$ & $\begin{array}{l}\begin{array}{l}\text { Glaeser, } \\
\text { Gyourko, \& Saiz } \\
(2008) .\end{array} \\
\end{array}$ \\
\hline & $\begin{array}{l}\text { The crisis resulted from the actions of U.S. housing } \\
\text { policies, greedy investment bankers, imprudent bankers, } \\
\text { incompetent rating agencies, shortsighted homeowners, } \\
\text { irresponsible housing speculators, and predatory mort- } \\
\text { gage brokers and lenders. }\end{array}$ & Wallison (2009). \\
\hline
\end{tabular}

\section{Literature Analysis}

Seeking potential answers to our inquiry regarding triggers to the housing market crash, our literature review focused on two fundamental questions: What forces colluded to create the housing bubble, and how did these forces collectively push the housing market to the precipice? Through our literature review we found a number of factors that directly or indirectly contributed to home price appreciation, 
which led to a hyperactive demand for housing and a massive bubble. Given the nature and complexity of our inquiry, we narrowed our attention to the impacts resulting from the following factors: a) the government monetary and housing policies b) the shadow banking system (existing outside of conventional lending channels), financial engineering of mortgages c) sub-prime market d) lending and underwriting standards. We also noted other less-critical, but relevant factors that collectively contributed to the bubble formation and subsequent burst.

\section{Government Monetary and Housing Policies}

Researchers are always interested in the government's role in any crisis. Questions pertinent to our inquiry centered around the following: 1) Did governments' policies provide fertile grounds for the bubble formation? 2) Did those policies, actions, or inactions, trigger the burst? Some have claimed that the expansion could not have happened without a substantial increase in the availability of mortgage debt for potential homeowners, which was a direct result of those policies.

Engel et al. (2016) argued that in an attempt to spur the economy following the dot-com bubble, the recession in 2000, the Enron bankruptcy, and the September 11th attack, the Federal Reserve slashed short-term interest rates and kept them low for an extended period. It wasn't until 2004 when the Federal Fund's rate increased gradually. The researchers concluded this decision resulted in an increase in housing prices of approximately 10\% nationally. Ritholtz (2011) posited that the Fed's policy of keeping short-term rates low also resulted in a lower yield for municipal and government bonds, forcing asset managers to find alternative investment vehicles. The higher yielding mortgage-backed securities presented the perfect opportunity.

Taylor and Silver (2009) suggested that by depressing the Fed Funds rate, the Federal Reserve contributed to the expansion of the housing market. L.H. White (2009) expanded Taylor's argument and placed blame on both the ill-advised monetary policies and the government's housing policies. He claimed that both policies were key contributors to the bubble formation and the crisis that ensued. His contention was that the monetary policies which kept the very short-term rates low in the early 2000's made adjustable rate mortgages (ARM) more attractive when compared to conventional fixed rate 30year mortgages. Naturally, low ARM rates opened borrowers to more expensive housing than they might buy otherwise and allowed more homeowners who were financially marginal to enter the market. He also suggested that borrowers assumed the Federal Reserve would maintain short-term rates low for an extended period. However, when ARM rates rose after their reset, affordability became an issue, and borrowers could no longer afford their monthly house payment. This resulted in delinquencies and home foreclosure. He also noted that government housing policies made the situation even more disastrous. By relaxing FHA down-payment standards and strengthening the Community Reinvestment Act, banks were pressured to provide home mortgages for low-income borrowers not considered as creditworthy. He added that the debt guarantees of the government sponsored entities, Fannie Mae and Freddie Mac, vastly contributed to the bubble.

Liebowitz (2008) suggested that by allowing weak mortgage underwriting standards the government contributed to the crisis. Speculators then had easy access to borrowed funds which spurred the demand for housing. When home prices deteriorated they quickly defaulted and exited the market. Gwartney et al. (2009) theorized that in addition to weak lending standards increasing the debt-to-income ratio for borrowers, the Federal Reserve's low shortterm rate policy amplified the financial leverage of investment bankers who took advantage of the low rates when they created their toxic assets. They later defaulted when they could no longer find alternative financing. Sowell (2009) focused on local governments and their land use restrictions contributing to the housing bubble. He suggested that given the limited supply of land, housing markets that were subject to those restrictions had the highest price increases.

Bernanke (2009) disagreed about the Government's role in depressing interest rates and furthering the crisis. He attributed low-interest rates, in part, to accumulated savings from emerging market economies flowing into the U.S. mortgage market, thus placing downward pressure on interest rates. In his view the low rates set by the Fed accounted for a small portion of the housing expansion. Jagannathan et al. (2013) expanded this by pointing to the "Global Savings Glut" that was seeking low-risk safe investments with better yields. They attributed the origin of the glut to the supply shock of labor in developing countries.

The massive labor supply coupled with innovation and the impact of globalization created massive amounts of savings in the emerging economies that 
were not invested domestically due to inadequate financial markets. They also argued that ultimately the foreign capital found its way into the U.S. real estate market where Wall Street engineered "highly rated bonds" backed by home mortgages. Ample mortgage financing was available and cheap consumer credit demand for housing increased, thereby laying the groundwork for a housing bubble.

Engel \& McCoy (2016) addressed another government policy: The huge push for homeownership by HUD. This increased pressure on government sponsored entities (GSEs) to provide mortgages for minorities and people with low or modest incomes. They stated that "subprime loans were presented as the key growth in homeownership by the Bush Administration" (Engel \& McCoy, 2016). The authors also emphasized the failure of Federal agencies and Congress to intervene even when horror stories of mortgage abuses were discovered early. The attitude of government officials then was that if there were problems in mortgage lending, the market would solve them.

Researchers found other policies to blame. Smith (2007) argued that the 1997 tax code encouraged overinvestment in residential real estate when it allowed homeowners to exclude up to half a million dollars in capital gains from the sale of their residences. Homeownership became a very attractive investment when compared to other financial investments, thereby fueling the housing bubble. Ritholtz (2011) pointed to the repeal of the Glass-Steagall legislation in 1998. The law, enacted in 1933, was intended to protect the banking system by prohibiting banks from certain activities, and separating them from hedge funds and investment banks. The repeal encouraged banks to take on more risky investments and enter the "innovative" mortgage loan markets, thereby fueling the housing bubble.

\section{The Shadow Banking System \& Financial Engineer- ing of Securitized Mortgages by Wall Street}

In the late 90's and early 2000's, a substantial amount of foreign capital seeking safe investments flowed into the U.S. financial system. As a result the demand for government bonds soared, depressing yields. Due to government monetary policy at the time keeping short-term rates low following the 2000 recession, Wall Street needed alternative investments with higher yields for these foreign investors.

Private label securitized home mortgages-those not sponsored by GSE's-presented the perfect opportunity. By bundling home loans into a trust providing monthly payments in a rated bond portfolio with home mortgages as collateral, Wall Street provided the perfect vehicle for investors needing strong returns. The securitization process, however, was not new, as government sponsored entities such as Fannie Mae and Freddie Mac had long securitized their mortgage portfolios when they acquired conforming loans from mortgage lenders, and thus replenished the funding for home loans. Seizing on the opportunity, a "shadow banking system" was created by highly leveraged entrepreneurs who became non-bank lenders funding home loans. Designated as "private lenders," they were not subject to regulation, and because they did not hold any customer deposits they did not fall under the jurisdiction of the FDIC. Private lenders understood that conforming loans sold to GSEs were not as profitable due to strictrules. Instead, they offered a variety of non-traditional mortgages to homebuyers and sold them to private Wall Street securitizers who packaged them as collateralized debt obligations or CDOs, and then wholesaled them to the ultimate investors. To achieve their goals and compete against government sponsored entities, they relaxed their underwriting mortgage lending standards, and specifically designed their business model to sell to Wall Street firms under the private label securitization market. By 2006, private underwriters were responsible for more than 12 million sub-prime mortgages valued at $\$ 2$ trillion, mostly issued to low and moderate income borrowers (Zywicki \& Okolski, 2009).

According to Krugman (2009b), the real culprit behind the crisis was this unregulated "shadow banking system." Camouflaged as private lenders, hedge funds and investment bankers saw great opportunities in packaging and selling collateralized debt obligations consisting of billions in home mortgages, thereby creating and feeding the housing bubble. He stated that they were bound to fail due to their highly leveraged make-up. Gorton (2009) agreed, adding that the credit crisis was merely a banking panic within the shadow banking system. These lenders failed when they were unable to obtain liquidity needed to increase the margins on their repossession agreements, or renew the sale and purchase of those agreements at the onset of the crisis.

Zandi (2008) confirmed that the financial engineering of securitizing mortgages into mortgage-backed securities lowered lending and underwriting standards. Mian et al. (2009) amplified the significance of securitized sub-prime mortgages when mortgage 
credit expanded into subprime zip codes. Vig (2009) provided more evidence that securitized loans resulted in a higher foreclosure rate than those loans held by banks as portfolio loans. Engel \& McCoy (2016) agreed that the securitization of mortgages allowed lenders to transfer all default risks to the investors, thereby creating a moral hazard. Private lenders had no incentives to improve the quality of the loans they produced since they earned their transaction fees upfront from borrowers and the securitization proceeds, and thus had no stake in the performance of the loans.

\section{Lending Products and Underwriting Standards}

To supply the ravenous lending machines, private lenders needed new mortgages. Therefore, they expanded their reach by implementing additional mortgage products while resorting to new techniques such as providing non-traditional mortgages and relaxing underwriting and loan terms. Examples of exotic mortgage loans provided to borrowers included the Hybrid ARM, interest-only loans, negative amortization loans, and pay-option adjustable mortgages. Also, by relaxing mortgage standards, credit for home purchases was easily obtained by additional borrowers, thus pushing the demand for houses even higher and resulting in more pressure on home prices. Whether it was a refinance or a home purchase, low down payments, low-doc or nodoc, stated income, high-loan-to-value, or piggyback loans--these represented some of the unique products used by lenders. Upper management also overruled loan underwriters and approved loans with "exceptions." Deception and fraud were inevitable as the frenzy continued. Subprime lending, a term used to describe loans to borrowers with blemishes on their credit, became the new description of a type of loan offered by many lenders. By the end of 2008, subprime mortgage debt including exotic mortgages reached \$2 trillion (Engel \& McCoy, 2016).

Lowering standards with low-doc home equity lines also allowed homeowners to use their homes as sources of cash when values rose, thus destroying equity they may have accumulated over the years. The continuing entry of speculators lured by rising prices and low mortgage underwriting standards pushed demand and prices even higher. Everyone was hoping to cash-in on the new gold rush.

Holt (2009) suggested relaxed mortgage standards were a direct result of government policies intended to improve homeownership rates among low-in- come households. Lenders reduced their underwriting standards to meet the requirements of the Community Reinvestment Act. Moreover, both Freddie Mac and Fannie Mae responded to HUD requests to increase the percentage of loans to lower income households by reducing income and down payment requirements. Bianco (2008) added the effect of a "moral hazard" to the lax mortgage standards since each actor in the mortgage transaction collected its profits and passed on the risk. To prove her point, she alluded to the drop in the denial rates during the bubble for conventional loans as reported in the Home Mortgage Disclosure Act.

\section{Subprime Market and Lending}

Subprime mortgage lending originated in 1980 with the Depository Institutions and Monetary Control Act that deregulated the banking industry. The Act ended state usury laws and allowed banks to charge interest rates based on the risks involved (Litrell \& Brooks, 2010). Due to higher risks, banks naturally charged higher rates and fees on certain loans, and sometimes even requiring credit life insurance policies. In those early days, however, much of the subprime lending was concentrated on refinances as opposed to financing new home purchases (Immergluck, 2004). The early refinances helped homeowners with equity manage and pay credit card debts while leveraging the tax deductibility of home

mortgage interest.

Technology, public policy, and securitization of mortgages, however, fueled the growth of the subprime market (Brescia, 2008). By 2006, subprime mortgages became mainstream with $20 \%$ of all originated mortgages and $25 \%$ of all securitized ones being subprime with the vast majority underwritten by unregulated private lenders (Zywicki \& Okolski, 2009).

Demyanyk (2011) found the quality of subprime mortgages deteriorated long before the onset of the Great Recession with the escalation in home prices concealing the problem. Gerardi et al. (2008) affirmed that the number of high loan-to-value subprime loans increased dramatically as the housing boom progressed. Those loans performed well in the early stages when prices were rising since borrowers had the ability to refinance or sell if they were uncomfortable with their mortgage payments. It is when prices began to decline that those mortgages quickly went underwater, pushing borrowers toward default and foreclosure. Mian et al. (2009) examined 
the expansion of subprime lending into subprime zip codes.

They discovered a high correlation of mortgage defaults with subprime zip codes, and from 2002 to 2005 , income and mortgage credit growth in those zip codes were negatively correlated. Adelino et al. (2016) refuted the zip code arguments which assumed that borrowers in poorer neighborhoods reflected the characteristics of those zip codes. To the contrary, Adelino found borrowers' income was double the neighborhoods' average and that most of the losses incurred were between middle-class and high-income borrowers. Also, the debt-to-income ratio of borrowers did not change when compared to the pre-bubble era.

Ferreira \& Gyouko (2015) also argued against those who blamed the subprime borrowers and subprime lenders for the housing crash. They concluded that prime borrowers were as responsible for causing the housing bubble. By analyzing foreclosure data from 1997 to 2012, they found that foreclosures of prime borrowers quickly outnumbered those of sub-prime mortgages. Because delinquencies and foreclosures started with the failure of sub-prime borrowers, researchers and the press jumped to the early conclusion that the sub-prime market was the major offender. Given the gravity of the crisis and the nature of exotic loans marketed by a few sub-prime lenders with bad practices, many of those lenders were equally blamed.

However, their data confirmed that sub-prime borrowers represented only $20 \%$ of the market, while the prime sector had $60 \%$ or more. When home prices fell $40 \%-50 \%$ in certain regions, a great number of prime borrowers stopped making mortgage payments even when they had made a $10 \%$ or $20 \%$ down payment. With the prospects of unemployment looming on the horizon, one solution that many borrowers resorted to was to mail the house keys to their lender, ultimately resulting in a foreclosure.

Their final analysis concluded that the real estate bubble was mostly the result of creditworthy borrowers who assumed that the value of their home would never decrease.

\section{Other Contributing Factors}

Krugman (2009a) articulated that for a bubble to form and inflate three prerequisites must be present. First, there must be a catalyst or reason causing investors to believe they can achieve higher returns without taking additional risks. Second, a liquidity source must be available to feed the bubble. Third, market inefficiencies or regulatory failures must exist, allowing the bubble to inflate without impediments. Examples of the catalysts from the Great Depression era were electricity and technological advances, such as the combustion engine. In the dot-com period, it was the promise of increased productivity from the internet which presented the convincing arguments. In the housing market crisis it was the thought that the Great Moderation which promised economic stability, economic growth, and low inflation could be maintained through financial innovations, market efficiency, and policymaking.

Shiller (2012) added his "Irrational Exuberance" theory, saying it was the "heightened state of speculative fervor" of all players in the marketplace that created the housing bubble. Haughwout et al. (2012) explored the impact of the excess supply of housing units generated by the housing industry. They concluded that the consolidation and growth of national builders contributed to the oversupply of units in a major way since they were already committed to projects in their pipeline well before price declines and tightening of the credit markets.

Glaeser (2008) maintained that it was the irrational demand during the housing bubble that resulted in sharp increases in home prices which extended its duration given the inelastic supply of housing. Wallison (2009) summed up his arguments by blaming all those that had a role in the debacle: the greedy investment bankers, the shortsighted homeowners, irresponsible speculators, imprudent bankers, incompetent rating agencies, bad housing policies, predatory mortgage brokers, and lenders.

\section{Discussion}

Scholars and the business press have outlined many hypotheses concerning the housing bubble, its burst, and the financial crisis that followed and which resulted in the Great Recession of 2007. Among those are the effect of the government's housing and monetary policies, the shadow banking system and the securitization of mortgage debts, the relaxing of mortgage underwriting standards, and subprime lending. Evidence also points to an abundant flow of foreign capital seeking good returns, and investment bankers accepting high risk without real government oversight. Other contributors were private lenders offering exotic home loans, as well as greed, fraud, and deceit among mortgage originators. Other forces fueling demand for housing included speculators who invested heavily in the residential real estate market, thereby adding more pressure on demand and exacerbating the crisis as they exited the market.

From a housing industry perspective, did these factors trigger the ensuing housing market crash, or did other underlying variables play a larger role? In addressing the question, one must keep in mind the business cycle in the background against which this series of events played out. Foldvary (1997) predicted that the 18-year business cycle following the 1990 
Table 2: 1997 Prediction of a major economic downturn in 2008 (Adapted from Foldvary, 1997)

\begin{tabular}{|c|c|c|c|c|c|}
\hline $\begin{array}{c}\text { Peaks in Land } \\
\text { Cycle Value }\end{array}$ & $\begin{array}{c}\text { Interval } \\
\text { (Years) }\end{array}$ & $\begin{array}{c}\text { Peaks in Con- } \\
\text { struction Cycle }\end{array}$ & $\begin{array}{c}\text { Interval } \\
\text { (Years) }\end{array}$ & $\begin{array}{c}\text { Peaks in Busi- } \\
\text { ness Cycle }\end{array}$ & $\begin{array}{c}\text { Interval } \\
\text { (Years) }\end{array}$ \\
\hline 1818 & -- & -- & -- & 1819 & -- \\
\hline 1836 & 18 & 1836 & -- & 1837 & 18 \\
\hline 1854 & 18 & 1856 & 20 & 1857 & 20 \\
\hline 1872 & 18 & 1871 & 15 & 1873 & 16 \\
\hline 1890 & 18 & 1892 & 21 & 1893 & 20 \\
\hline 1907 & 17 & 1909 & 17 & 1918 & 25 \\
\hline 1925 & 18 & 1925 & 16 & 1929 & 11 \\
\hline 1973 & 48 & 1972 & 47 & 1973 & 44 \\
\hline 1979 & 6 & 1978 & 6 & 1980 & 7 \\
\hline 1989 & 10 & 1986 & 8 & 1990 & 10 \\
\hline 2006 & 17 & 2006 & 20 & 2008 & 18 \\
\hline
\end{tabular}

downturn would cause the U.S. economy to have a major downturn around 2008 assuming no major interruptions to the cycle, as shown in Table 2. Although such predictions by economists always provoke disagreements, it is important to understand the business cycle and its impact on the market as a whole.

With an extended expansion of the housing market from the mid-1990s through the mid-2000s, the homeownership rate increased from $64 \%$ to $69 \%$. Although a few percentage points may not seem substantial, it represents what appeared to be an additional 15 million households entering the housing market and acquiring properties they called home. The expansion also coincided with a strong appreciation of home values in certain regions of the country. An examination of home prices shows they remained in concert with general prices as measured by the CPI until 1995. Beginning with 1996 and ending in 2006, the Case-Shiller National Real Housing Price Index rose from 80 to 190, and home prices skyrocketed, as shown in Figure 5. The average home price more than doubled between 1998 and 2006, representing the largest recorded increase in U.S. history. Economist Robert J. Shiller previously warned, however, that housing price increases beyond the general inflation rate could not be sustained long term. The serious decline in home prices that followed severely dropped the index to a low of 125 in 2012 and resulted in a sharp decline in property values leading to a significant rise in defaults and foreclosures.

Since the Great Depression home prices in the U.S. had never experienced such a cycle of surge and decline (Byun, 2010). We believe this phenomenon of a sharp rise and substantial fall of home prices in such a short time frame had the greatest impact on the housing market, leading to the severe market correction.

Therefore, it appears that when residential homes turned from being a shelter for families to being a commodity traded through complex financial instruments by Wall Street professionals--a new unsustainable demand for housing was produced. With ample liquidity, loose underwriting, and easy credit, the rapid acceleration in prices occurred. The base level organic demand was augmented by non-organic demand from speculators and "flippers" wanting simply to cash in on rising values. In 2005 alone, 28\% of homes were purchased by speculators for investment purposes, while an additional $12 \%$ were for a second home. The resulting excess demand and ensuing bidding wars that followed caused rapidly increasing prices as the market sought a new equilibrium. In addition, studies have shown that to meet the artificially increased demand the housing industry produced nearly 3.5 million excess units nationally during the boom years (Haughwout et al., 2012). The lag time for land acquisition, development, and construction of new homes explains why the industry continued to oversupply the market with more units even after the bubble burst. This lagging oversupply resulted in a substantial downward pressure on prices.

\section{Effect of Government Monetary and Housing Policies}

The literature reflects that the low short-term rate policy set by the Federal Reserve in the early 2000's encouraged the flight of investments from low earning government bonds into higher yielding mortgage-backed securities. The real downward pressure on interest rates, however, came from the invested savings flowing from emerging economies (Ber- 


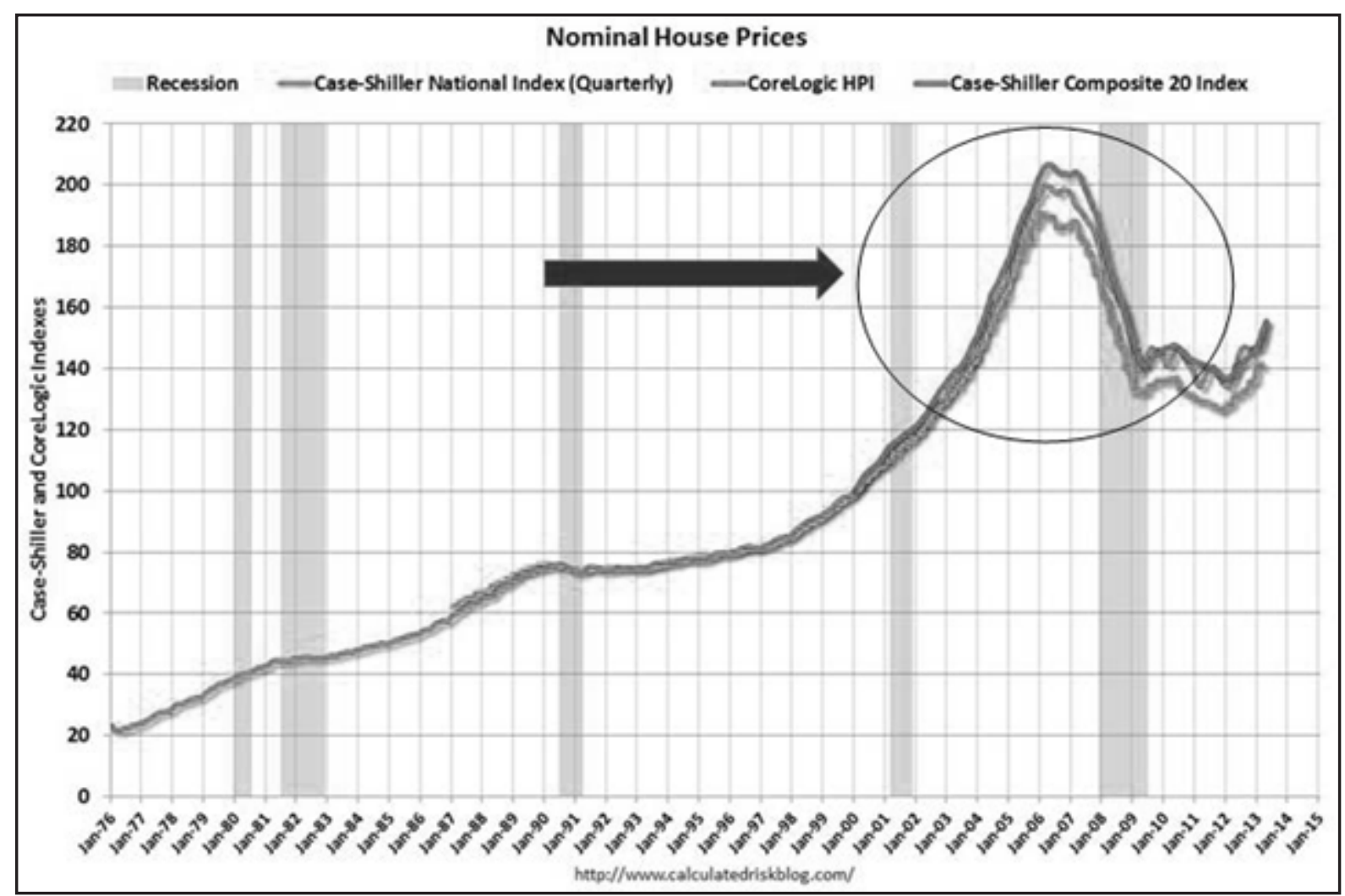

Figure 5: Evidence of Bubble in Case-Shiller Housing Index

nankey, 2009). Foreign investments from sovereign funds, Europe, Brazil, oil producing countries, and China, were substantial. With globalization, money had been chasing investments with safe and solid returns worldwide, and the U.S. presented the perfect opportunity at the time. Investors saw a great investment in the U.S. real estate market through the rated and insured securitized mortgages that carried a favorable coupon rate. There is no doubt the housing expansion benefited from low rates, but to claim that government monetary policy was responsible for the housing bubble, in our opinion, lacks the evidence supporting those views and shows very little merit.

Critics also attribute the housing bubble to government housing programs and policies. They point to the role played by the Housing and Urban Development Agency (HUD), the government-sponsored entities Fannie Mae and Freddy Mac, and the actions of the Clinton and Bush administrations in encouraging homeownership. The Community Reinvestment Act of 1977 (CRA), which promoted community development by encouraging financial institutions to help meet the credit needs of local communities received much criticism due to foreclosures despite contrary data that dispute its contribution (Littrell \& Brooks, 2010). Proponents argue that if the implementation of CRA rules was the reason behind so many foreclosures, then defaults should have occurred in the suburbs where the housing boom happened as opposed to inner cities and in-fill projects where the CRA was mainly emphasized. Those proponents also added that the CRA mandate not only deterred discrimination and predatory lending to working-class borrowers and minorities, but also served those communities with safe and sound lending practices resulting in lower foreclosures (Taylor \& Silver, 2009). The Financial Crisis Inquiry Commission in its final report, along with economists from the Federal Reserve, provided additional support to the views that government housing policies, including loans in CRA districts, were not a major cause of the crisis.

Over the years most government policies and agencies acted in ways to facilitate and promote homeownership by easing barriers. Creating the demand for housing, however, is a market function. Moreover, since much of the housing price escalation took place long after the Federal Reserve tightened its monetary policy, the funds rate did not contribute to the rise in home prices. Thus, the argument blaming the government for inflating the bubble does not appear to meet the rigor test. If government agencies are to share any blame it would be in the absence of meaningful public oversight of certain market functions, specifically those pertaining to the credit agencies. 


\section{Role of Subprime Lending and Borrow- ers}

Many early conclusions pointed to subprime borrowers as being irresponsible for accepting lending terms that were unrealistic, thus causing the mayhem in the housing market. The rationale given was the fact that the number of subprime delinquencies and foreclosures in the early days of the bubble burst far exceeded the number of prime foreclosures. New studies have shown, however, that only $20 \%$ of foreclosures resulted from subprime lending, while the majority were prime borrowers that defaulted for a variety of reasons. Also research has revealed that, during the bubble, lenders placed prime borrowers in the subprime category, so they could earn higher fees and process loans faster. Lenders even went as far as classifying loans as a subprime due to the loan characteristics, regardless of the credit standing of the borrowers. Another important consideration that deserves exploration is the timing effect on subprime borrowers. One may argue that, in better times, many would have fulfilled their loan obligations. Job losses, a faltering economy, actions of the banking industry, and most of all the sharp drop in home equities made circumstances extremely difficult even for the most creditworthy borrowers. Whether subprime borrowers would have defaulted if the timeframe for their loan time cycle were different requires further analysis.

\section{Impact of Adjustable Rate Mortgages}

Researchers also blamed the adjustable rate mortgages (ARMs) and the rate resets for the bubble burst. They stated that as rates reset, after an initial period with a fixed "teaser" rate, borrowers faced a mortgage payment shock and stopped making payments on their loans. However, ARMs were not a new mortgage product. When Congress decided in the early 1980s to deregulate the banking industry and abolish interest rate caps on home mortgages, banks introduced new mortgages including ARMs. These mortgages appealed to borrowers due to offering a lower rate than comparative fixed rate mortgages.

Many homeowners assumed they would be in their home for only a few years, thus a lower monthly payment would be advantageous. As long as they could refinance if rates changed or could sell their property, the rate reset was seen as irrelevant. The fact that a high number of financed ARM mortgages in the 1980s through the early 2000's did not create any problems for lenders suggests that they were not a key ingredient of the bubble burst. Only when refinancing was not available, or a falling real estate market created negative equity, did adjustable or hybrid mortgages become problematic.

\section{Conclusion}

In purely economic terms, the painful housing market crash was merely a severe correction which brought the market close to equilibrium. Dynamics of supply and demand apply regardless of the type of commodity traded. Homebuyers, speculators, government actions and policies, GSE's, Wall Street, hedge funds, and other players in the private sector all contributed toward inflating the housing bubble. Its burst was imminent as the sharp rise in home prices was not sustainable. There is no doubt that the fraudulent activities performed by some participants in the mortgage industry resulted in harm and pain for many. Their impact, however, was small in the grand scheme of the bubble burst. Researchers did raise concerns as to whether the homebuilding industry was culpable in fueling the bubble given that overbuilding in certain markets did happen. This was evidenced by the additional 3.5 million units produced during the bubble (Haughwout et al. 2012). The behavior of homebuilders, however, was rational as they operated to fulfill market needs for residential units, and many had to complete projects already underway. In addition, Wall Street and equity markets that financed projects for national builders demanded a continuous stream of revenues (Zywicki \& Okolski, 2009). The significant consolidation of homebuilders which occurred in the 1990's and early 2000's may explain why national builders produced more units in some markets and kept their building machines at full capacity. The herding behavior of builders in markets full of uncertainty also encouraged some overbuilding. They relied on positive signals received from worthy competitors about future demand prospects and chose to ignore the signals of bad economic conditions (Banerjee, 1992).

The role of the "Big Three" rating agencies, Fitch, Standard \& Poor's, and Moody's Investors services, however, is debatable. The Financial Crisis Inquiry Commission reported the rating agencies were "key enablers of the financial meltdown." Supposedly, they were the independent gatekeepers in the financial markets responsible for rating the debt instruments and securities for investors and lenders, as well as for debtors' financial ability to repay obligations. In this fiduciary responsibility they failed to properly assess the risks associated with those securities, which allowed the financial markets to flood the residential lending market with substantial liquidity. There is no doubt that investors would have reconsidered the purchase of those securities if the rating agencies quantified risk factors correctly. This would have resulted in alternative investment vehicles being created for the liquidity that fueled the housing bubble. 


\section{References}

Adelino, M., Schoar, A., \& Severino, F. (2016). Loan originations and defaults in the mortgage crisis: The role of the middle class. 29(7). The Review of Financial Studies, 1635-1670.

Amadeo, K. (2017). AIG bailout: Cost, timeline, bonuses, causes, effects: Why it made Bernanke angrier than anything else in the recession. The Balance. Retrieved from https://www.thebalance. com/aig-bailout-cost-timeline-bonuses-causes-effects-3305693

Baker, D. (2002). The run-up in home prices: A bubble. Challenge, 45(6), 93-119.

Banerjee, A. V. (1992). A simple model of herd behavior. The Quarterly Journal of Economics, 107(3), 797-817.

Bernanke, B. S. (2009). Four questions about the financial crisis. Atlanta, Georgia: Board of Governors of the US Federal Reserve System: Speech at the Morehouse College.

Bianco, K. M. (2008). The subprime lending crisis: Causes and effects of the mortgage meltdown. New York: CCH, Wolters Kluwer Law \& Business.

Bivens, J. (2011, September 16). When did the meltdown really begin? [Blog post]. Retrieved from http://www.epi.org/blog/lehman-brothers-collapse-anniversary/1347066155000/

Blumgart, J. (2016). What will become of Levittown Pennsylvania? Atlantic City Lab, 7-14.

Brescia, R. H. (2008). Capital in chaos: The subprime mortgage crisis and the social capital response. Clev. St. L. Rev., 56, 271-318.

Bricker, J. K., Kennickell, A.B., Moore, K.B. \& Sabelhaus, J. (2012). Changes in U.S. family finances from 2007 to 2010: Evidence from the survey of consumer finances. Federal Reserve Bulletin, 98(2), 1-80.

Burgard, S. A., Brand, J. E., \& House, J. S. (2007). Toward a better estimation of the effect of job loss on health. Journal of health and social behavior, 48(4), 369-384.

BusinessWire (2005). Fortune magazine names Bear Stearns 'Most Admired' securities firm. BusinessWire, 25 February. Retrieved from http://www. businesswire.com/news/home/20050225005422/ en/FORTUNE-Magazine-Names- Bear-Stearns-Admired-Securities

Byun, K. J. (2010). The US housing bubble and bust: Impacts on employment. Monthly Labor Review, 133(12).

Carter, G.R. \& Gottchalck, A.O. (n.d.). Drowning in debt: Households with underwater mortgages.
U.S. Census Bureau. Retrieved from https://www. census.gov/content/dam/Census/programs- surveys/ahs/publications/Drowning_in_Debt.pdf

Case, K. E., Quigley, J. M., \& Shiller, R. J. (2005). Comparing wealth effects: the stock market versus the housing market. Advances in Macroeconomics, 5(1).

CBPP. (2012). The state of the residential construction industry. Center on Budget and Policy Priorities.

CBPP. (2017). Chart Book: The legacy of the great recession. Center on Budget and Policy Priorities, 12 September 2017. Retrieved from: https://www. cbpp.org/research/economy/chart-book-the- legacy-of-the-great-recession

Dao, M., \& Loungani, M. P. (2010). The human cost of recessions: Assessing it, reducing it. International Monetary Fund.

Demyanyk, Y. \& Van Hemert, O. (2011). Understanding the subprime mortgage crisis. Review of financial Studies, 24(6), 1848-1880.

Denning, S. (2011). Lest we forget: Why we had a financial crisis. Forbes. 22, Retrieved from https:// www.forbes.com/sites/stevedenning/2011/11/22/ 5086/\#1e45ec86f92f

Engel, K. C. and McCoy, P.A. (2016). The subprime virus: Reckless credit, regulatory failure, and next steps. Oxford University Press.

Ferreira, F. \& Gyouko, J. (2015). A new look at the US foreclosure crisis: Panel data evidence of prime and subprime borrowers from 1997 to 2012. National Bureau of Economic Research Working Paper No. 21261. Retrieved from http://www.nber.org/ papers/w21261.

Foldvary, F. E. (1997). The business cycle. American Journal of Economics and Sociology, 56(4), 521524.

Gagnon, J., Raskin, M., Remache, J., \& Sack, B. (2010). Large-scale asset purchases by the Federal Reserve: Did they work? Federal Reserve Bank of New York, Staff Report no. 441, March. Retrieved from https://www.newyorkfed.org/medialibrary/ media/research/staff_reports/sr441.pdf

Gerardi, K. L. (2008). Making sense of the subprime crisis. Brookings Papers on Economic Activity, 69159.

Giuliano, P., \&. Spilimbergo, A. (2009). Growing up in a recession: Beliefs and the macroeconomy. $\mathrm{Na}-$ tional Bureau of Economic Research Working Paper 15321. Retrieved from http://www.nber.org/ papers/w15321

Glaeser, E. L., Gyourko, J., \& Saiz, A. (2008). Housing supply and housing bubbles. Journal of Urban Economics, 64(2), 198-217. 
Gorton, G. B. (2009). Slapped in the face by the invisible hand: Banking and the Panic of 2007. Oxford University Press.

Gould Ellen, I., \& Dastrup, S. (2012). Housing and the Great Recession. Stanford Center on Poverty and Inequality.

Greiner, B. (2015). There's is no place like home-the housing market and economic growth. Forbes. Retrieved from https://www.forbes.com/ sites/billgreiner/2015/08/20/theres-no-placelike-home- the-housing-market-and-economic-growth/\#740131f7404a

Gwartney, J., Macpherson, D., Sobel, R., \& Stroup, R. (2008). Special Topic: The crash of 2008: Cause and aftermath. Commonsenseeconomics.com. Retrieved from http://commonsenseeconomics. com/wp-content/uploads/CSE_CrashOf2008_ Aug10.pdf

Hanke, S. (2010). The great 18-year real estate cycle. Globe Asia, 2, 22-24.

Haughwout, A., Peach, R. W., Sporn, J., \& Tracy, J. (2012). The supply side of the housing boom and bust of the 2000s. In Glaeser, E. L. and Sinai, T. (Eds.) (2013) Housing and the financial crisis (pp. 69-104). University of Chicago Press.

HBS (2017). Bubbles, panics \& crashes. Harvard Business School-Historical Collections. Retrieved from https://www.library.hbs.edu/hc/crises/

Helbing, T., \& Terrones, M. (2003). Chaper 2: When bubbles burst. IMF World Economic Outlook, April 2003. 61-90.

Holt, J. (2009). A summary of the primary causes of the housing bubble and the resulting credit crisis: A non-technical paper. The Journal of Business Inquiry, 120-129.

Immergluck, D. (2004). Credit in the community. Armonk, NY: ME Sharpe.

Independence Title. (2014). Why housing is important to the economy? Independence Title, 1 August 2014. Retrieved from http://independencetitle. com/why-housing-is-important-to-the-economy/

Jagannathan, R. K. (2013). Causes of the great recession of 2007-2009: The financial crisis was the symptom not the disease! Journal of Financial Intermediation, 22(1), 4-29.

Krugman, P. (2009a). How did economists get it so wrong? New York Times Magazine, 2 September. Retrieved from http://www.nytimes. com/2009/09/06/magazine/06Economic-t.htm1 ? $\mathrm{mcubz}=1$

Krugman, P. R. (2009b). The return of depression economics and the crisis of 2008. New York: W.W. Norton.
Liebowitz, S. J. (2008). Anatomy of a train wreck. Independent Policy Report.

Littrell, J. \& Brooks, F. (2010). In defense of the community reinvestment act. Journal of Community Practice, 18(4), 417-439.

Mian, A., \& Sufi, A. (2009). The consequences of mortgage credit expansion: Evidence from the U.S. mortgage default crisis. The Quarterly Journal of Economics, 124(4), 1449-1496.

NAHB. (2015). The economic impact of home building in a typical local area: Income, jobs, and taxes generated. Housing Policy Department report, April 2015. National Association of Home Builders.

Picardo, E. (2015). Five of the largest asset bubbles in history. Investopedia. Retrieved from http:// www.investopedia.com/articles/personal-finance/062315/five-largest-asset-bubbles- history. asp

Quint, R. (2015). US government: Number of builders declined 50\% between 2007 and 2012. National Association of Home Builders.

Reinhart, C.M. \& Rogoff, K.S. (2009). This time is different: Eight centuries of financial folly. Princeton University Press.

Ritholtz, B. (2011). Examining the big lie: How the facts of the economic crisis stack up. Washington Post, 19 November. Retrieved from http://ritholtz. com/2011/11/examining-the-big-lie-how-thefacts-of-the-economic-crisis-stack-up/

Roth, J. (2016). A short history of the U.S. housing market. Money Boss. Retrieved from http://moneyboss.com/housing-market-history/

Shiller, R. J. (2012). The subprime solution: how today's global financial crisis happened, and what to do about it. Princeton University Press.

Smith, V. L. (2007). The Clinton housing bubble. Wall Street Journal Online, 18.

Smith, W. B. (1935). Fluctuations in American business, 1790-1860. Cambridge: Harvard University Press.

Sowell, T. (2009). The housing boom and bust. New York: Basic Books.

Stevens, A. \& Schaller, J. (2009). Short-run effects of parental job loss on children's academic achievement. National Bureau of Economic Research Working Paper No. 15480. Retrieved from http:// www.nber.org/papers/w15480.

Taylor, J. \& Silver, J. (2009). The Community Reinvestment Act: 30 years of wealth building and what we must do to finish the job. Revisiting the CRA: Perspectives on the Future of the Community Reinvestment Act, 148-159. 
Vig, V. S. (2009). Securitization and distressed loan renegotiation: Evidence from the subprime mortgage crisis. Society for Economic Dynamics. Society for Economic Dynamics. Meeting Papers (No. 1169).

Wallison, P. J. (2009). Cause and effect: government policies and the financial crisis. Critical Review, 21(2-3), 365-376.

White, E.N. (2009). Lessons from the great American real estate boom and bust of the 1920s. NBER Working Paper Series, Working Paper 15573, Retrieved from http://www.nber.org/papers/w15573

White, L. H. (2009). Housing finance and the 2008 financial crisis. Downsizing the Federal Government. Retrieved from https://www.downsizinggovernment.org/hud/housing-finance-2008-financial-crisis.

Woodward, C. (2015). How does the housing market affect the economy? OneNewsNow.com. Retrieved from https://www.onenewsnow.com/busi- ness/2015/06/22/how-does-the-housing-marketaffect-the-economy

Worldatlas (2016). Countries with the highest homer ownership rates. Worldatlas.com. Retrieved from http://www.worldatlas.com/articles/countries-with-the-highest-home-ownership-rates. html

Zandi, M. (2008). Financial shock: A 360o look at the subprime mortgage implosion, and how to avoid the next financial crisis. FT Press.

Zywicki, T., \& Okolski, G. (2009). The housing market crash. Mercatus Center, George Mason University.

\section{Review}

This article was accepted under the constructive peer review option. For futher details, see the descriptions at:

http://mumabusinessreview.org/peer-review-options/

\section{Acknowledgments}

This article derives from Chapter 1 of Dr. Hasbini's doctoral dissertation titled "The Great Recession of 2007 and the Housing Market Crash: Why Did So Many Builders Fail? Lessons for the Local Homebuilding Industry"

\section{Biographies}

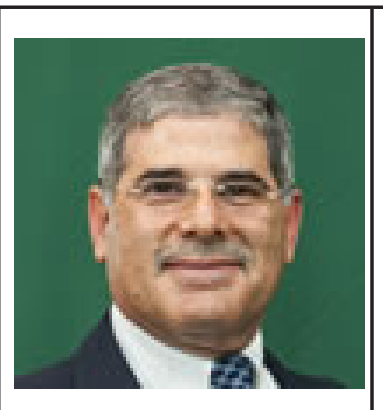

Ali Hasbini is the president and chief executive officer of Sunrise Homes Inc. and Transcend Development Corp. Over the past 30 years, he has developed more than 40 communities and built 3,000+ homes in the region. His companies are also involved in the construction and development of commercial and industrial projects. Hasbini's companies have received numerous awards from the Tampa Bay Builders Association and he received the USF Alumni Association's "Entrepreneur of the Year Award."

Hasbini earned an MBA with a concentration in finance and a Bachelor of Science in Accounting, both from USF. He is a Certified Public Accountant and a Class "A" State Certified General Contractor. He received his DBA in 2017.

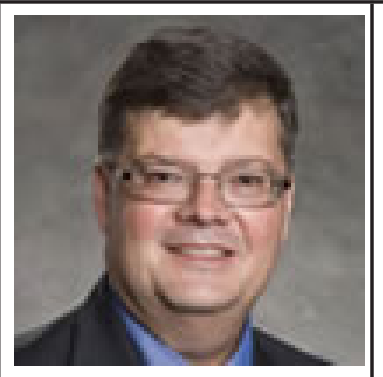

Ron Satterfield is an instructor in the Information Systems Decision Sciences Department of the USF Muma College of Business, teaching courses in statistics, operations management, and process improvement. He teaches these courses in the USF undergraduate, MBA, Executive MBA, MS in Business Analytics and Information Systems, and Doctorate of Business Administration programs.

Satterfield earned a PhD in Operations Management from the Kelley School of Business at Indiana University and an MBA and BA in operations management from Eastern Illinois University. He is a board member and chair of the IT Committee for the USF Federal Credit Union. 